\title{
Research on the Network Data Mining Application in the College Ideological and Political Education
}

\author{
Li Pingquan \\ Students' Affairs Department, Chuzhou Vocational \&Technical College, Chuzhou \\ 239000, Anhui, China \\ lpq0550@126.com
}

\begin{abstract}
With the development of information technology and network education, as a kind of new teaching method, educational data mining has been widely concerned. In this paper, the author analyzes the data mining application in the college ideological and political education. Through big data mining, the author analyzes the present situation of Ideological and political education, and points out the key points of Ideological and political education reform, including theoretical reform, practical reform and examination reform. At the same time, we analyze the development of Ideological and political education in the context of new media. The result shows that the new media has played an important role in the cultivation of college students' ideological guidance, learning and aesthetic appreciation. Teachers should make full use of new media to strengthen ideological and political education.
\end{abstract}

Keywords: Data Mining, Network media, Ideological and political education, Education work

\section{Introduction}

Research on data mining began in 1980s, and has been successfully applied in the fields of business, finance, marketing and so on. The development of educational information and network to carry out distance education, all kinds of data in the field of education leads to rapid growth, how to dig out of education and learners useful information from the mass data, in order to improve the education management performance and learning performance, this paper urges educational data mining research. The extensive application of information technology in the field of education to promote the development of education and scientific research of information, the information of scientific research (E-research) refers to the information technology "to" scientific research practice, its development has experienced the following three stages: one is the research stage of the technology, such as technological innovation, technology applications, such as digital divide; two is studied by the technology, such as computer aided interviews, technical support for data analysis, social network analysis and so on; three is the technical research stage, such as data mining, data processing, data integration, data analysis, simulation, visualization etc. Education data mining is the embodiment of digital education research, but also the inevitable demand of the development of educational information.

College Ideological and political course is the main way of Marx theory education for college students, and the ideological and political education is the main education link. In the ideological and political education background, to constantly enhance the ideological and political education theory and practice of college students as the main goal of education, promote college students' Ideological and political thought of healthy growth, achieved remarkable results and survival in the society in. The development and changes of the society make Higher Vocational Ideological and political education is facing new 
challenges, how to do the ideological and political education of higher vocational students in today's complex situation at home and abroad, to promote the teaching reform of Ideological and political education, not only is one of the important work of the school is also an important issue facing the country and social concern. New media is in the condition of new technology such as digital media, magazines, newspapers, radio, television, mobile phone SMS, MMS, Internet blog, micro-blog, China in the past 10 years the Internet, mobile phone, digital TV and other media quickly from scratch, some people have to popularize, deeply affected in our social life, especially have a direct and profound influence on the new media have a keen interest in young people. Therefore how to use the new media to effectively carry out ideological and political education of college students has become a very important issue.

\section{Educational Data Mining}

\subsection{Data Mining}

Data mining (DM), which is synonymous with knowledge discovery in databases (KDD), refers to the non trivial process of extracting meaningful, implicit, previously unknown and potentially valuable information or patterns from large databases. The research contents of DM including basic theory research and applied research in two categories, which include basic theory research method, function, algorithm and construction of data mining system and software aspects of research on the application of data mining technology is not in itself, but in the application of the results, application of different in different fields. Educational data mining (EDM) process of extracting meaningful information refers to the application of data mining methods come from the education system in the data, the information for educators, learners, educational managers, software developers and education researchers to provide services. EDM focuses on data mining application in the field of education, from the analysis of the research field of EDM EDM research perspective, including the "application" in teaching research and application in educational administration in two sub categories; from the analysis of data source view, including "EDM research in the application of traditional education and" Application "in the network education of the two sub categories, combining these two aspects can be further subdivided for EDM research.

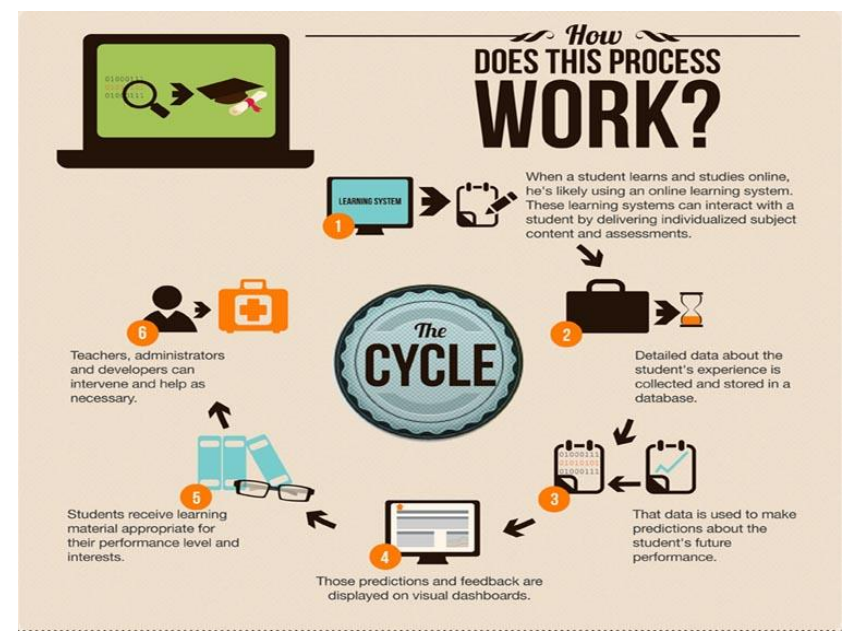

Figure 1. Data Mining in Education

Data mining technology can be applied in enrollment, employment, logistics, library management, personnel management, equipment management, teacher management, etc., to help managers make scientific decisions. EDM is more important to guide and improve 
learning, improve the quality of teaching, especially in the application of network education. The network learning environment is not like face-to-face feedback through the traditional classroom, but most can record students' learning behavior, through the network learning system of the learner in the registration information, log files, process data, interactive information and management data of the excavation, such as how many people visited the page, where it comes from what is the end users to access the page, the most popular, the page may be what the next step is to determine the characteristics of the learner model and so on, individual or group, manage and monitor the network learning process, personalized learning support of students, teaching and curriculum design, build an effective learning mode, and improve the system modify the site construction, suitable for learning resources, evaluation of teaching and learning, to provide services for page recommendation and intelligent learning, can also be used for Analysis of the loss of students in network learning, teaching decision-making, etc.

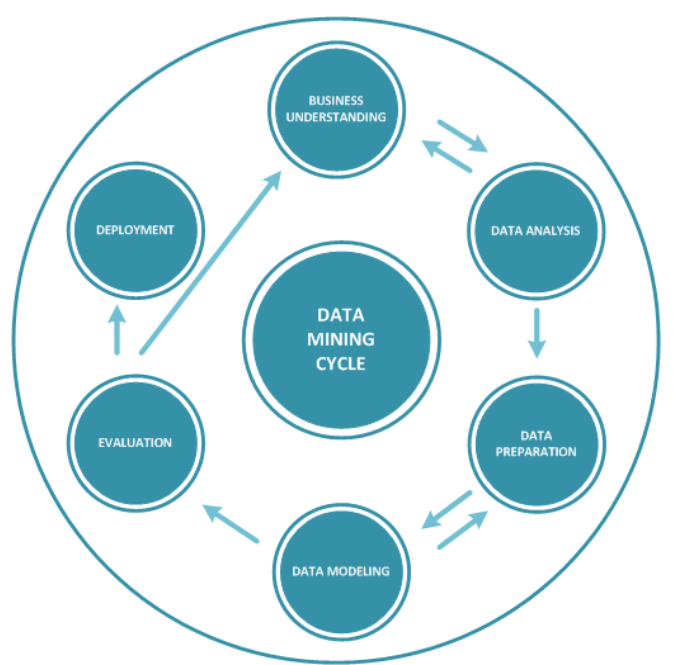

Figure 2. Data Mining Process

Support vector machine SVM is based on a pattern recognition method of minimizing the $\mathrm{VC}$ dimension theory and structural risk theory of statistical principle, mainly used in the field of pattern recognition, can solve the small sample, nonlinear, high dimension and local minimum problems, machine learning has become one of the hot research field, and successfully applied to pattern classification, function approximation and time series prediction etc. The key to support vector machine SVM is the kernel function, which is the most attractive place. The low dimensional space vector set is usually difficult to classify, the solution is to map them into a high dimensional space, but it can bring the difficulty is that the increase in computational complexity, and the kernel function just cleverly solved the problem. That is to say, as long as we choose the appropriate kernel function, we can get the classification function of high dimensional space. The research of support vector machine SVM is the two kind of linear separable problem in pattern recognition.

$$
R(\pi)=\int L(y, f(x, \pi)) d F(x, y)
$$

Therefore, the expected risk of $\mathrm{R}(\pi)$ to replace the experience of risk:

$$
R_{\text {emp }}(\pi)=\frac{1}{l} \sum_{i=1}^{l} L\left(y_{i}, f\left(x_{i}, \pi\right)\right)
$$


If the expectations of the risk $\mathrm{R}(\pi)$ and empirical risk $\mathrm{R}_{\mathrm{emp}}(\pi)$ according to the convergence of probability $p$ to the same limit inf $R(\pi)$ is called empirical risk minimization principle is consistent.

$$
R(\pi) \leq R_{\text {emp }}(\pi)+\sqrt{\frac{h \ln \left(\frac{2 l}{h}\right)-\ln \left(\frac{\eta}{4}\right)}{l}}
$$

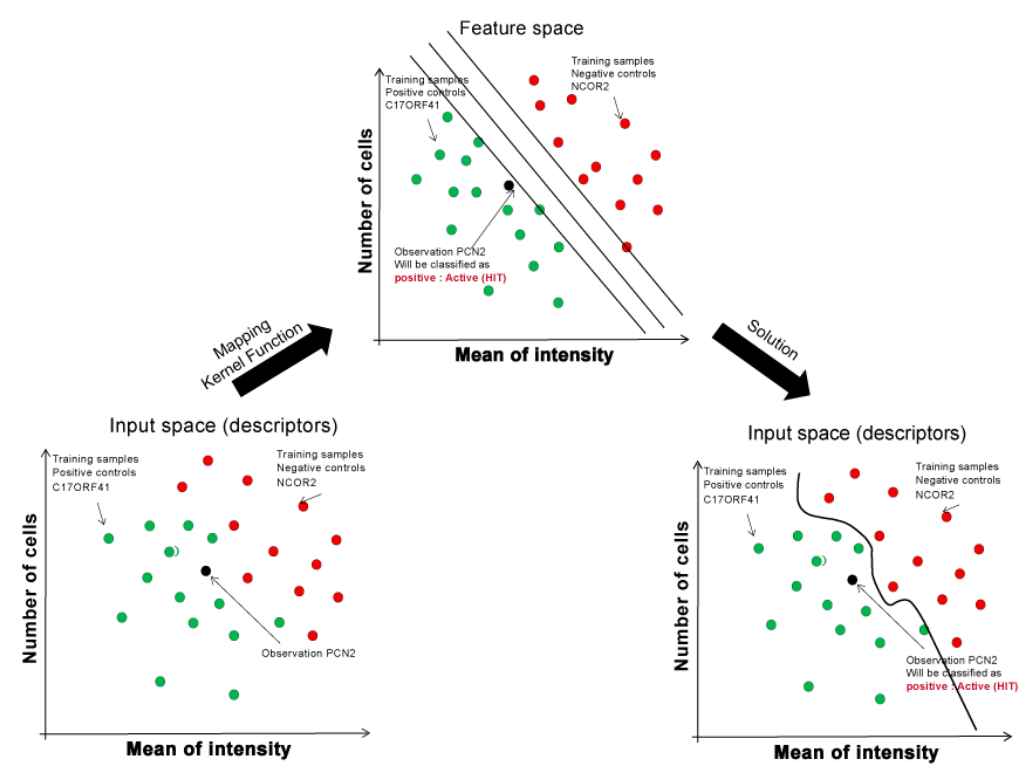

Figure 3. Support Vector Machine

The use of educational data mining method is the most critical content of EDM research. Romero a detailed description of the related literatures on 1995-2005 EDM from several EDM tools, EDM data source, education method, is to understand the authority of foreign EDM development, on the basis of their tasks will be used for a particular data mining method in the network education system is divided into statistics and visualization and Web mining two.

- Statistics and visualization: Data mining the descriptive data analysis technology itself as objective, formal statistical hypothesis test based on tend to be as the ultimate goal, visualization is the data information into meaningful, easy to understand image, although they are often not considered the data mining technology, but as a detection method for data. They can handle some common problems by data mining.

- Web mining: Web mining is the process of obtaining information from WWW resources, and it is the application of data mining technology in Web environment. On the basis of the mining of different objects can be divided into three categories: Web mining, Web content mining, Web structure mining and Web usage mining, Web usage mining in the log application research in network learning most, Through the log information left in the network education to mining the learners to achieve network personalized education. In Web usage mining, the network learning behavior collection and learner's characteristic analysis is the key. 


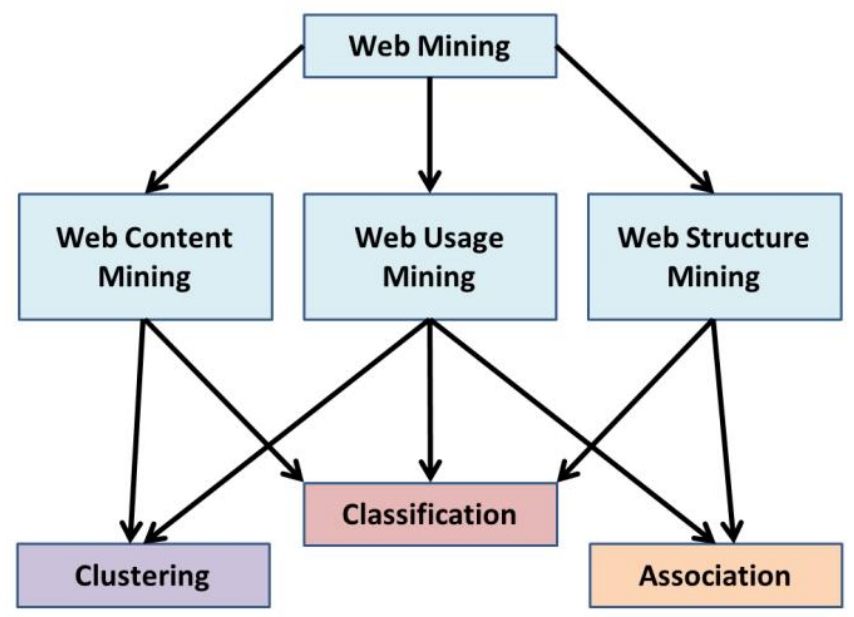

Figure 4. Web Mining

1) Clustering, classification and deviation detection: Clustering is a process of combining physical or abstract objects into multiple classes or clusters composed of similar objects. Classification is used to classify the data items by mining some common characteristics of the data, and the classification or clustering method is used to classify the students' groups or individuals in order to provide similar or personalized teaching.

2) Association rule mining and sequential pattern mining: Association rule mining is used to access the database sequence from the user's dig out the relevant rules in sequence, can reveal the learners access to some content and access the content, to find related content, page and page organization recommended courses can be better, as far as possible to shorten the distance distribution of relevant content, or provide the path convenient guide.

3) Text mining: Web text mining is mainly on the contents of a large number of text collections on the Web summary, classification, clustering, association analysis and the use of Web documents for trend prediction, etc., is for unstructured or semi-structured data sets

\section{Reform of Ideological and Political Education in Universities}

\subsection{The Connotation of Ideological and Political Education}

From the value of Ideological and political education, its essence is to meet the needs of real people and social development in the ideological and political education. Secondly, the ideological and political education is the needs of different students are classified, then there are unreasonable requirements of students' Ideological and political education, let the students in the pursuit of objective interests at the same time, the realization of self value, the relationship between the different needs are interrelated, ideological and political education is to implement the subjective needs of people first in practice. The main goal of Ideological and political education is to solve all kinds of ideological struggle, in order to meet the students' development and the realization of the self value of the students as the main point of exploration. To correctly evaluate college students to realize their self value, they should be evaluated from the contribution to the society. This is a correct ideological and political road, to the students to be educated, will let the students fully understand their social status, and the contribution to the society.

Ideological and political education in Colleges and universities to strengthen the students to fully study the ideological and political education, training students' Ideological and political thinking. First of all, in the teaching of Ideological and political 
courses in Colleges and universities is a "social practice" teaching, according to the "CPC Central Committee Propaganda Department of the Ministry of education to further strengthen and improve the College Ideological and political theory course put forward opinions" practice education and classroom education combined. It will be effective classroom and practice activities extend to the life, life with positive thoughts and the political, ideological and political education and teaching content combine to encourage students to become a good citizen with positive thinking and good students.

\subsection{Ideological and Political Education Reform}

Ideological and political education is one of the important education courses in Colleges and universities, ideological and political education in the eyes of most college students is a boring subject. Teachers in the classroom to teach students ideological and political theory of knowledge, so that students cannot fully understanding the meaning of Ideological and political education. Now after the education reform, put forward the "big government" concept of teaching, vocational school ideological and political education courses have undergone significant changes, will be among the teachers and students of the main object position exchange. Teachers pay attention to the development of students' personality thinking, and it is no longer a direct ideological and political ideas. The current ideological and political education of college students, it is to advocate the student-centered teaching concept, change the traditional teaching way. With the development of modern information technology, the teaching of Ideological and political education in Colleges and universities has gradually begun to use science and technology teaching methods to stimulate students' enthusiasm and interest. After great efforts to strengthen the ideological and political education of college students, has achieved good results, the students in the community has greatly reflected the role of Ideological and political education.

Ideological and political education, although the results are significant, but there are still many deficiencies. Part of the school senior leadership of the ideological and political education of the importance is not enough, leading to the neglect of Ideological and political education of school teachers and related funding, students' Ideological and political teaching is not enough fresh, unable to keep up with the pace of development of modern ideological and political education. In the classroom teaching has not completely from the traditional education mode, the teaching equipment is relatively backward, unable to meet the needs of the development of contemporary college students. The training of students' professional skills is much higher than that of Ideological and political education, which leads to the low interest of students in Ideological and political education.

- Adhere to the ideological and Political Education: On the ideological and political course teaching reform must adhere to the "University Ideological and political teaching concept, establish the" big ideological and political "education ideas, actively promote the teaching reform. The "big government" is the ideological and political education of college, it refers to the inheritance of the traditional ideological and political education, and adapt to the development of new politics in which shows the cultural innovation in Higher Vocational colleges.

- Theoretical education reform: The theory of education reform is mainly reflected in the following aspects: one is to grasp the key points of the textbook, a comprehensive analysis of the teaching contents, teaching change to complete chapter two is the topic teaching; follow up teaching schedule, to achieve the "three close", pay more attention to the teaching content of teaching materials; three is the use of education means, from the application of teaching, implementation the government wants to education and the beginning of high school, to the integration of teaching objectives; four is to make full use of the side of the story, contains the 
truth to promote students' moral growth. Using theoretical education to promote the cultivation of students' political quality, moral character and healthy personality.

- Practical education reform: Practical education reform is mainly based on innovation, application and science. The implementation of Ideological and political education can be carried out from three centers for reform. First of all, in the ideological and political class in the use of "problems" to carry out practical teaching, for example, in the middle school students through activities, lectures, reports and other forms of analysis to practice learning ideological and political theory. This will practice together learning methods and theory can not only improve the students' Ideological and political interest in learning, cultivate the ability of students, but also can promote the interaction between teachers and students; secondly, the construction of campus culture in the campus teaching center based in Ideological and political class, which is effective to extend the classroom knowledge in the campus, and guide students to participate in practical activities in the form of.

- Examination mode reform: University evaluation method of reform, can effectively improve the motivation of learning. Schools adhere to the unity of knowledge and evaluation methods, the total score of Ideological and political courses generally include the examination papers, grades, practice achievements of three plates. Which factors will the students performance and moral quality into the credit assessment, which can full of students, fair assessment, to reflect the students' Ideological and political education, promote the teaching is closely related to the ideological and political education, to guide students to establish a good ideological and moral quality of the image, thus the true sense of the increase of Ideological and political teaching.

\section{Development of Ideological and Political Education in the Context of New Media}

\subsection{New Media Communication}

The development of the Internet and mobile media has a profound impact on our social life, especially for the young people who have a strong interest in the new media. The new media has grown from a tool of the passive role gradually transforms to the influence and control of human thought and behavior of the active role, characteristics of new media is the largest amount of information huge fast transmission, frequent updates, it also contains a large number of unfiltered information over uneven in quality, the adverse effects of these for the inexperienced, thought immature students. They not only take on cultivating students' professional skills, but also the ideological and political quality and quality will also have the responsibility of training, so how to use new media to effectively carry out the ideological and political education of college students has become a very important topic.

- Generalization of communication information: The information dissemination of traditional media has a very strong hierarchy, the different information through the traditional media has its own limit of the spread of the. The new media from the beginning of the formation of the transmission diversity, information transmission is not linear but nonlinear, dual level communication into a generalization of the state, all publish information, any information released by him and the new media can be seen by all. The new media era, high degree of openness, freedom and twoway communication between the crowd broke the social, cultural and psychological tangible original or invisible barriers, instant messaging feature of new media makes people communicate more freely, without time and geographical constraints. 
- "Fragmentation" of communication information: In the era of new media carrier, ways and channels of information dissemination has changed and information dissemination of the contents of "the same pieces together again through new media, play a multiplier effect of information influence. The traditional media era, a few a few kinds of media control public opinion influenced the whole society, the arrival of the new media era on the one hand, the traditional media market share shrinking, authoritative information and dissemination effect decreases, on the other hand is the rapid rise of emerging media, massive expansion of innovation mode of transmission the amount of information and communication, build a new stage of social development of new social relations, market relations, thought consciousness, credit system and the language form and information dissemination effect system.

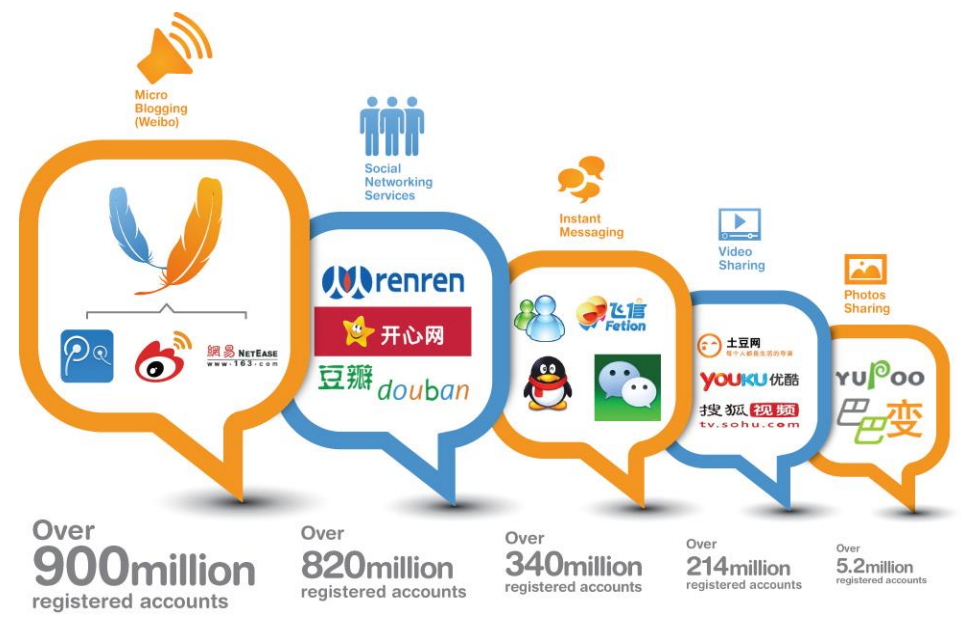

Figure 5. New Media Communication

\subsection{The Function of New Media on the Ideological and Political Education}

The rapid development of new media on campus, many types of influence for ideological and political education in Colleges and universities, workers, the emergence of new media has become an effective way to college students' ideological trend, has become an important carrier of Ideological and political education of college students; on the other hand, due to the rapid information dissemination of new media are extensive and difficult control to the current more effectively carry out the ideological and political education work puts forward new challenges.

(1) the new media has played an important role in the cultivation of College Students' ideological guidance, learning and aesthetic appreciation.

College students for the frequency of use of new media, has become the main source of information about the outside world, the party and state policies, and major events at home and abroad, the requirements of the school through the new media to convey to the students. The new media information dissemination speed, audio-visual, vivid image, through the new media of the typical events and characters of college students in the publicity to multi form, omni-directional and multi perspective of education, help to improve university students' political quality and morality, help students to establish a correct outlook on life and world outlook. College students use the Internet the most time of the new media, the school can let students learn more about the school management system, the school's management approach and the concept of running school. Students can through the network according to their own interests, to find their own personal strengths such as "fellow traveler", a positive and healthy discussion can make better 
communication between peers, more scientific and rapid growth. College Students' ideological guidance, learning and communication, life and entertainment, interest in the aesthetic of the new media through the effective channels to get more training, exercise and improve.

(2) the new media is full of bad information to the ideological and political education of college students to bring the impact

QQ chat, online games, e-mail, micro-blog, BBS forum these emerging media is the vast majority of college students everyday life learning network tools, the information publishing platform has yet to establish a sound unhealthy, vulgar, reactionary information filtering mechanism, these harmful things will impact their immature outlook on life values and world outlook. These new media tools invented mostly western developed capitalist countries, these countries in the use and management of the new media on the forefront, in the entire media tools using rulemaker role, some websites and blogs would be the western capitalist countries, to every corner of the world to promote western bourgeois ideology and politics the system of culture and ideology, which for college students are vulnerable to these ideological and cultural impact. The popularity of the new media makes it easy for these unhealthy Internet information to spread among college students and influence their behavior, so that their values are more likely to go to extremes. Especially the popularity of the campus of the new media dissemination of Western capitalist countries ideology smoothly, so long to indulge in the network, mobile phone of the young students in the traditional culture of indifference, is not conducive to the inheritance and development of the advanced traditional culture.

\subsection{Countermeasures and Suggestions on Strengthening Ideological and Political Work of College Students}

(1) college education managers should master the skills, enhance the awareness of the concept of change

The main reason for college students to carry out ideological and political education is university teachers, because of the differences in age, university teachers and students' learning and living media use channels are different. Renren.com, micro-blog, BBS and other students in the forum, everyone will use a lot of new media tools in the part of university teachers are not generally used, the educator and the communication channel is currently out of touch must face up to the problem. The University Ideological and political teachers should be more students, students' media habits and channels and master, by friends forms of students equal exchanges and dialogue, actively carry out positive guidance and all-round multi angle communication with students, through the new media to build communication channels to understand the ideological situation of the students, to solve the problem of student thought.

(2) strengthen the media literacy education of College Students

Under the new media environment, it is a great challenge to carry out the media literacy education of college students. Media literacy education from the concept to the realization, the need for all aspects of the community to work together. Some scholars point out that the media organizations, social organizations, and the audience are the main body of the new media. Media organization is the main body of the media literacy education system. The social organization is the main body of the media literacy education system, and the audience is the main body of the media literacy education system. College Students' media literacy education needs to start from three aspects: the school, the society and the college students themselves, with the three aspects of the media, social factors and personal factors. 


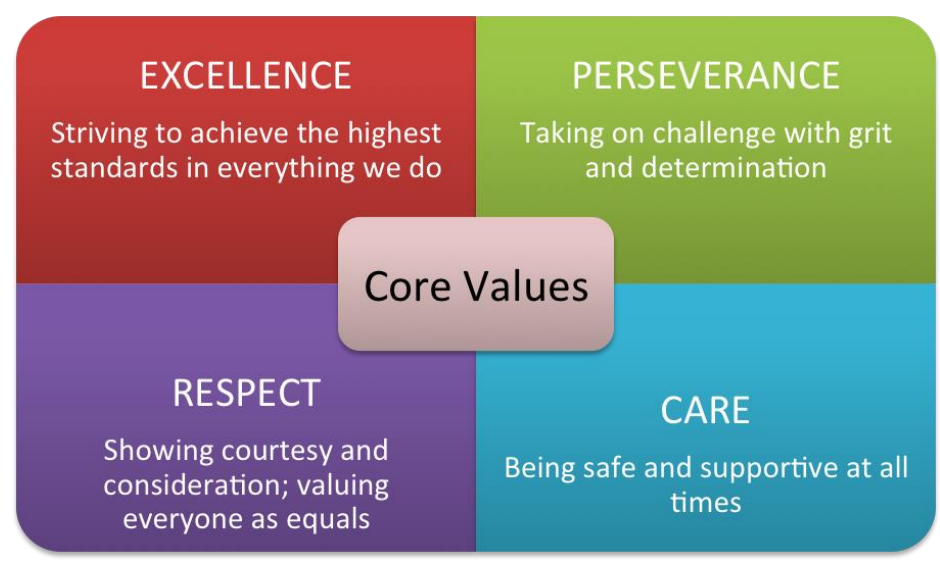

Figure 6. The Core Value of College Students

\section{Conclusions}

Use the new media to carry out ideological and political education of college students should not abandon our original ideological education forms and means, any form of education is not to face the communication with students in the real world, the traditional ideological and political education can effectively promote the network virtual world education form together better the effect of online network. Pay attention to the method and the intensity of supervision, in the process of carrying out online ideological and political education, scientific use of "clear", "guide" two ways. To enable the students to express their own inner world of thoughts and feelings fully in the free state of the dredging process, to stimulate students to develop their own rational thinking ability in network practice, can accurately understand the thinking of the students and makes the students in emotional expression. The guide is to optimize the information resources from the network, such as the teacher's web blog, counselors, personal websites, through some of the packaging to achieve the purpose of Ideological and political education. To dredge and guide is not only the important method and form of College Ideological and political education, the scientific guidance is an effective way to lead the ideological and political education of college students in the new media era.

\section{References}

[1] R.Khansa, "Teachers' Perceptions toward School Counselors in Selected Private Schools in Lebanon”, Procedia - Social and Behavioral Sciences, Vol.185, (2015), pp.381-387.

[2] C.Krstev, and A.Trtovac, "Teaching Multimedia Documents to LIS Students", The Journal of Academic Librarianship, Vol.40, No.2,(2014), pp.152-162.

[3] R.A.Sabella, "School counselors perceived importance of counseling technology competencies", Computers in Human Behavior, Vol.26, (2010), pp. 609-617.

[4] N.R.Mastroleo, R.Turrisi, "Examination of posttraining supervision of peer counselors in a motivational enhancement intervention to reduce drinking in a sample of heavy-drinking college students",Journal of Substance Abuse Treatment, Vol.39, (2010), pp.289-297.

[5] Z.Huang and M.Benyoucef, "From e-commerce to social commerce: A close look at design features",Electronic Commerce Research and Applications, Vol.12, No.4, (2013), pp.246-259.

[6] C.Zhang, X.Chen, "Use of Multimedia in Gross Infective Pathogen Experimental Teaching", Procedia Engineering, Vol.37, (2012), pp.64-67.

[7] W.Dai, L.Fan, "Discussion about the Pros and Cons and Recommendations for Multimedia Teaching in Local Vocational Schools",Physics Procedia, Vol.33, (2012), pp.1144-1148.

[8] S.Jian-hua, L.hong, "Explore the Effective Use of Multimedia Technology in College Physics Teaching”,Energy Procedia, Vol.17, (2012), pp.1897-1900. 


\section{Authors}

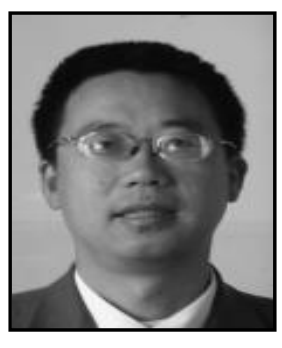

Li Pingquan, 1966.2, Chuzhou, Anhui, P. R. China, Current position, grades: the associate professor of Students' Affairs Department, Chuzhou Vocational \&Technical College, Chuzhou Anhui, China. Scientific interest: he research interest fields include Ideological and political education of College Students and compute education. Publications: more than 10 papers published. Experience: he has teaching experience of 16 years, has completed three scientific research projects. 
International Journal of Database Theory and Application Vol.10, No.1 (2017) 